\title{
Использование виртуального симулятора роботов в обучении школьников основам визуального программирования
}

Степанова А.И., магистрант, Северо-Восточный федеральный университет, 2. Якутск E-mail: anzh.stpnva@mail.ru

\section{Научный руководитель: к.ф.-м.н., доцент Максимов В.В.}

Образовательная робототехника прочно вошла в образовательные программы дополнительного образования детей. Занятия робототехникой способствуют вовлечению детей в процесс инженерно-технического творчества, формированию у них навыков решения практических задач проектирования, конструирования и программирования технических устройств, а также развитию коммуникативных способностей и приобретению опыта эффективного взаимодействия в процессе групповой работы над проектами.

Робототехнику можно использовать в начальном, основном общем и среднем (полном) общем образовании, в области начального профессионального образования, а также специального (коррекционного) обучения. Он дает возможность на ранних шагах выявить технические наклонности учащихся и развивать их в этом направлении.

Для обучения детей основам робототехники в основной и старшей школе широко используются образовательные робототехнические наборы LEGO Mindstorms NXT, LEGO Mindstorms EV3, RoboRobo RoboKit, HUNA/MRT, ТРИК, наборы на базе микроконтроллера Arduino и т.п. Каждый из этих наборов имеет свою графическую среду программирования роботов.

Одним из интересных направлений образовательной робототехники является управление и программирование виртуальных роботов. Виртуальные роботы обычно являются виртуальными симуляторами реальных роботов и могут использоваться как для ознакомления детей с ними, так и для отладки программ управления ими. Рассмотрим наиболее известные из них [1, 2, 3]:

1. Microsoft Robotics Developer Studio - система, которая может использоваться для управления не только реальными роботами, но и их симуляторами. Она содержит язык Visual Programming Language (VPL), предназначенный для разработки программ управления роботами, и среду визуализации Visual Simulation Environment, позволяющую экспериментировать с моделями роботов и тестировать алгоритмы управления ими. Программа на языке VPL представляет собой последовательность блоков, которые выполняют обработку данных, и связей между ними.

2. Robotino SIM Professional - виртуальная учебная среда для работы с автономным мобильным роботом Robotino. В этой среде можно создавать различные виртуальные трехмерные рабочие среды, а затем моделировать выполнение программ управления роботом Robotino.

3. Gazebo 3D - среда для симулирования работы виртуальных роботов с различными сенсорами. 
4. Code Rally - симулятор гонок машин («роботов») по трассе, который позволяет тестировать различные алгоритмы управления роботом на своем компьютере, посоревноваться с друзьями по сети или запустить приложение на облачном сервере.

5. RoboCup Soccer Simulation League - симулятор игры двумерных и трехмерных роботов в футбол.

6. TRIK Studio - среда для программирования роботов ТРИК, содержащий двумерный симулятор этих роботов.

Одним из самых востребованных областей использования виртуальных симуляторов роботов является обучение детей основам программирования роботов. Наиболее простой для изучения и в то же время обладающей достаточно широкими возможностями для симуляции роботов средой является TRIK Studio. Эта система относится к категории свободно распространяемого программного обеспечения, имеет интуитивно понятный русскоязычный и графический интерфейс и, самое главное, поддерживает программирование не только отечественного робота TRIK, но и самых популярных в мире роботов LEGO Mindstorms NXT и EV3 [3].

Ниже приведен пример программы езды виртуального симулятора робота по черной линии с использованием датчика света в среде TRIK Studio (Рис 1).

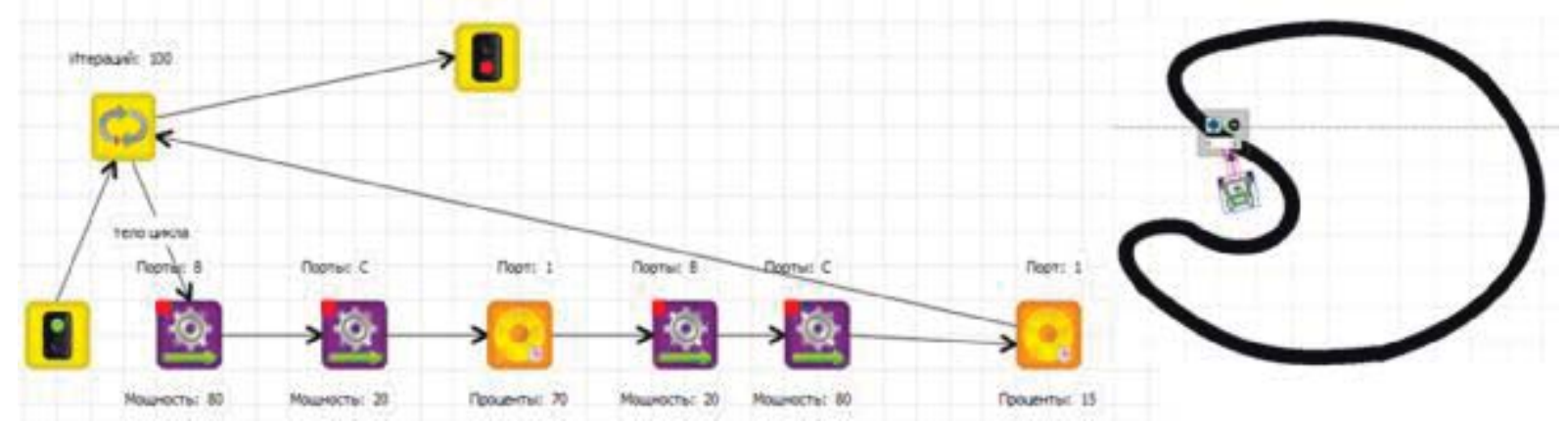

Рис. 1. Езда по черной линии

Перед тем, как составить программу управления роботом, учащиеся сначала должны сконструировать и собрать робота, отвечающего тем или иным требованиям, и только после этого они могут составлять и отлаживать программы для решения поставленных задач по управлению роботом, каждый раз загружая эти программы с компьютера в контроллер робота и запуская их. При программировании виртуального робота в среде TRIK Studio учащиеся получают возможность изучать алгоритмы и составлять программы управления движением и действиями робота с использованием различных датчиков, в т.ч. датчика цвета и сонара, не загружая программу в контроллер реального робота.

При решении сложных задач, например, в робототехнических соревнованиях, отладка и выбор наиболее подходящей программы требуют многократного редактирования и загрузки составленных программ с компьютера в контроллер робота для проверки их правильности и эффективности. В таких случаях среда визуального программирования роботов TRIK Studio может быть использована для предварительного анализа и проверки различных вариантов алгоритмов и программ.

Среда визуального программирования TRIK Studio как универсальное программное обеспечение может применяться также и на дополнительных занятиях по информатике для изучения и закрепления тем по основам алгоритмизации и программирования. 
Нами подготовлен комплект задач с решениями для использования их в обучении школьников программированию роботов в среде TRIK Studio. Задачи предназначены для составления линейных, разветвляющихся и циклических программ с использованием функций и подпрограмм для управления роботами, снабженными датчиками касания, света, цвета, сонаром и маркером. Апробация данного комплекта проводилась на отдельных занятиях для школьников, занимающихся в кружках робототехники, и обучающих семинарах для учителей информатики и педагогов. Ведущих занятия по робототехнике. В дальнейшем комплект задач будет использован в дистанционном курсе по основам программирования роботов в среде TRIK Studio.

\section{Список литературы:}

1. Виртуальные миры роботов [Электронный ресурс]. - Режим доступа: http://www.robotvirtualworlds.com/.

2. Гай B.E. Microsoft Robotics Developer Studio. Программирование алгоритмов управления роботами. - М.: ЭКОМ Паблишерз, 2012. - 184 с.

3. Филиппов С.А. Уроки робототехники. Конструкция. Движение. Управление. М.: Лаборатория знаний, 2017. - 176 с.

4. Сайт TRIK Studio [Электронный ресурс]. - Режим доступа: http://blog.trikset.com/2015/02/trik-studio-30.html\#more

\section{Абитуриентские предпочтения чукотских выпускников 2017 года}

Тыльваль О.А., студент, Чукотский филиал

Северо-Восточного федерального университета

Научный руководитель: к.n.н. Попов C.M.

В 2017 году средние школы Чукотки окончит 361 выпускник. Около 500 человек получат дипломы о среднем профессиональном образовании или свидетельство об уровне квалификации по рабочей профессии в Чукотском многопрофильном колледже, Северо-Западном техникуме г. Билибино, Северо-Восточном техникуме пос. Провидения, Полярном техникуме пос. Эгвекинот Иультинского района.

Часть из них в сентябре 2017 года продолжит получение образования, другие - на работу, в армию, замуж, еще год готовиться к ЕГЭ, чтобы улучшить свои результаты и поступить в вуз или просто подумать, определиться с выбором и дальше строить свою судьбу там, где получается.

Есть выбор вынужденный, есть по зову сердца, но если это не криминал, лень или пьянство, то всякий выбор достоин уважения. Не всегда человеку на выпуске вовремя приходит осознание, что выбор делать уже пора, что плыть по течению - не лучшее занятие.

Но для осознанного выбора выпускникам зачастую не всегда хватает информации. А Чукотке нужны молодые квалифицированные кадры. Это - проблема. Ее следует всесторонне изучить, потому что она актуальная. 